\title{
EFFECT OF PENICILLIN TREATMENT ON SERUM COMPLEMENT LEVELS IN ACUTE RHEUMATIC FEVER
}

\author{
BY
}

\author{
A. F. SCHUBART, H. J. ROTHSCHILD, W. C. SCHROEDER, R. W. EWALD, \\ AND J. D. TUERK \\ From the Division of Arthritis, Department of Medicine, University of Maryland School of Medicine, \\ Baltimore, Maryland
}

Serum complement levels are determined in various diseases for two main reasons: first, any deviation from normal may be used for differential diagnostic purposes, and secondly, alterations in serum complement levels may be of pathogenetic significance in that they indicate the participation of the complement system in the disease process.

In acute rheumatic fever, serum complement levels have been found to deviate significantly from normal. Fischel, Pauli, and Lesh (1949), and Fischel, Frank, Boltax, and Arcasoy (1958) and Williams and Law (1958) reviewed the literature when reporting their own data. Raised levels were found predominantly during the early course of rheumatic fever. Longitudinal studies with repeated complement determinations by Fischel, Pauli, and Lesh (1949) have shown raised lev: ls to persist in some cases for up to 7 weeks during and after the course of acute rheumatic fever.

In this paper correlation with clinical data indicates that the administration of salicylates does not influence the persistent elevation of serum complement levels. The effects on complement of treatment with sulphonamides or antibiotics were not correlated. Furthermore, in these studies, serum complement levels were measured at long and irregular intervals which did not permit the observation of transient fluctuations. Therefore, it appeared desirable to study the serum complement levels in a longitudinal fashion with frequent complement determinations, paying special attention to the duration of the illness and various clinical manifestations as well as to treatment.

It is the purpose of this paper to describe significant changes in serum complement levels found after starting treatment in forty cases of acute rheumatic fever.

\section{Methods}

Forty patients with acute rheumatic fever were studied clinically and serologically while in the University
Hospital, Baltimore, Maryland. Patients were admitted to the study according to the modification of the criteria of Duckett Jones (1944) set forth in the U.K. and U.S. joint reports on rheumatic fever $(1955,1960)$, and signs and symptoms were assessed and recorded daily.

Blood was drawn under sterile conditions at various times from all forty patients with acute rheumatic fever, sera from sixty normal persons serving as controls. Serum was obtained by centrifugation of clotted blood (incubated at room temperature for less than $2 \mathrm{hrs}$ ), and was stored at $-70^{\circ} \mathrm{C}$.

Serum complement levels were determined and expressed in $\mathrm{C}^{\prime}-\mathrm{H}_{50}$ haemolytic units according to the technique of Mayer (1961). The haemolytic unit of complement was defined as the amount demonstrated in $1 \mathrm{ml}$. which will lyse $2.5 \times 10^{8}$ optimally sensitized red cells out of a total of $5 \times 10^{8}$ cells in the presence of optimal $\mathrm{Ca}^{+}+$and $\mathrm{Mg}^{++}$ions at an ionic strength of 0.147 with $1 \frac{1}{2} \mathrm{hrs}$ incubation at $37^{\circ} \mathrm{C}$. in a total volume of $7.5 \mathrm{ml}$. A "vor-test" using various serum dilutions was employed to make a rough estimate of the point of 50 per cent. haemolysis. The result of this "vor-test" constituted the basis for the main test which was then carried out with four dilutions set up for each serum in duplicate, together with four control tubes. The Beckman Spectrophotometer DB 19 was used at a wavelength of 541 millimicrons. The results were plotted on logarithmic paper and the number of 50 per cent. haemolytic units was calculated. The inclination of the slope of the graph was used as a guide for accuracy. Results were considered acceptable when found within the \pm 0.02 or 10 per cent. deviation from the mean value of $\frac{1}{n}=0.02$.

Sterile sheep cells in Alsever's solution and lyophilized guinea-pig complement were obtained from the Cappell Laboratories, West Chester, Pennsylvania.

The various serum specimens of every patient with acute rheumatic fever were stored at $-70^{\circ} \mathrm{C}$. Determination of complement levels of all specimens of the same patient was performed simultaneously by the same investigator with a standardized technique, including the daily determination of the complement level of a control 
serum (control serum was stored in small aliquots at $-70^{\circ} \mathrm{C}$.)

The following parameters were determined at weekly intervals: haematocrit, erythrocyte sedimentation rate (method Wintrobe, corrected by the Whitby and Hines chart to a haematocrit of 45 per cent.), white blood count, antistreptolysin-O titre, and C-reactive protein.

\section{Results}

(1) Determination of Serum Complement Levels in Sixty Normal Control Sera.-Complement levels of sixty normal sera were expressed in $\mathrm{C}^{\prime}-\mathrm{H}_{50}$ haemolytic units (Fig. 1). The values ranged from 25 to $59 \cdot 4 \mathrm{C}^{\prime}-\mathrm{H}_{50}$ units (mean $40 \cdot 2 \mathrm{C}^{\prime}-\mathrm{H}_{50}$ ). Daily complement determination of aliquots of one control serum revealed a maximal error of $\pm 3 \cdot 1$ units. The standard deviation was calculated to be $2 \cdot 55 \mathrm{C}^{\prime}-\mathrm{H}_{50}$ units. In 100 determinations of complement in aliquots from one control serum, 96.6 per cent. of the values were found to be within the range of 1 standard deviation, i.e. $2 \cdot 55 \mathrm{C}^{\prime}-\mathrm{H}_{50}$ units.

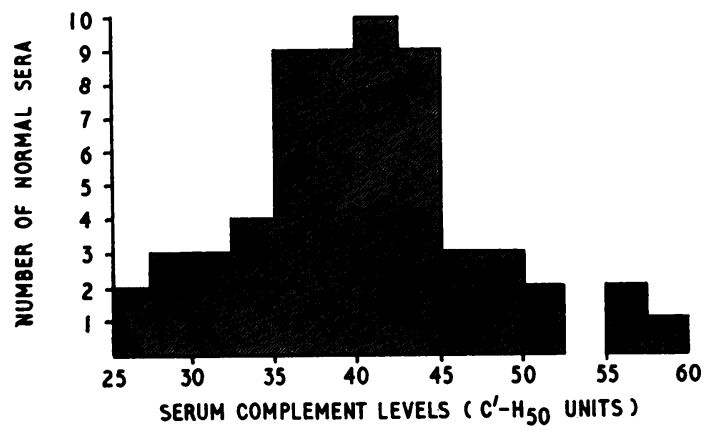

Fig. 1.-Serum complement levels in sixty healthy individuals.

(2) Determination of Serum Complement Levels in Forty Cases of Acute Rheumatic Fever.-The complement levels of the first serum specimens obtained after admission to hospital of the forty patients with acute rheumatic fever are shown in Fig. 2. Nineteen

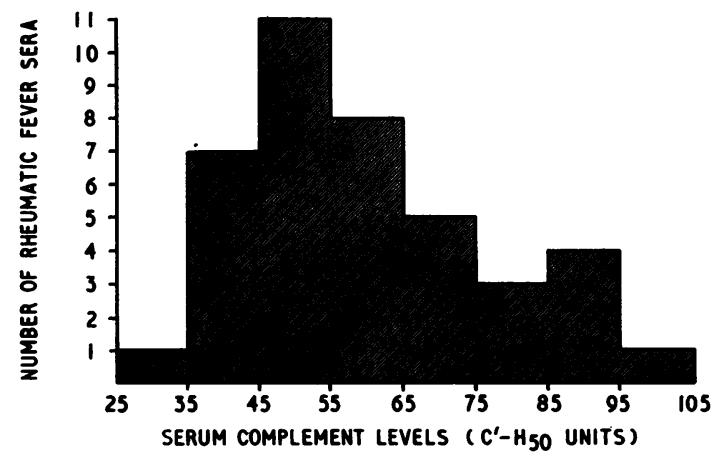

Fig. 2.-Complement levels of first serum specimens obtained after hospitalization from forty patients with rheumatic fever. were below $55 \mathrm{C}^{\prime}-\mathrm{H}_{50}$ units (i.e. within the range of normal), and 21 were found to be raised.

Serial Determination of Complement Levels during the course of hospitalization:

Nineteen patients with normal complement levels on admission.-The majority (fourteen cases) showed only minor changes on consecutive examinations, and the levels remained within normal range. In Cases 1 and 2 the values were found to be below normal during hospitalization (Fig. 3).

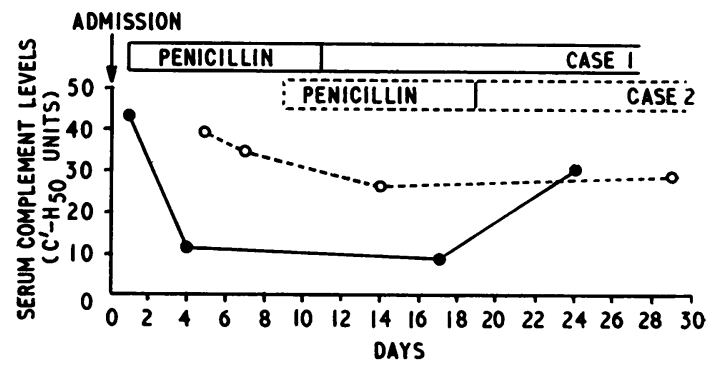

Fig. 3.-Serum complement values reduced below normal in Cases 1 and 2 during the course of acute rheumatic fever.

Three patients (Cases 3, 4, 5) exhibited rising complement levels which returned to normal within 10 days (Fig. 4).

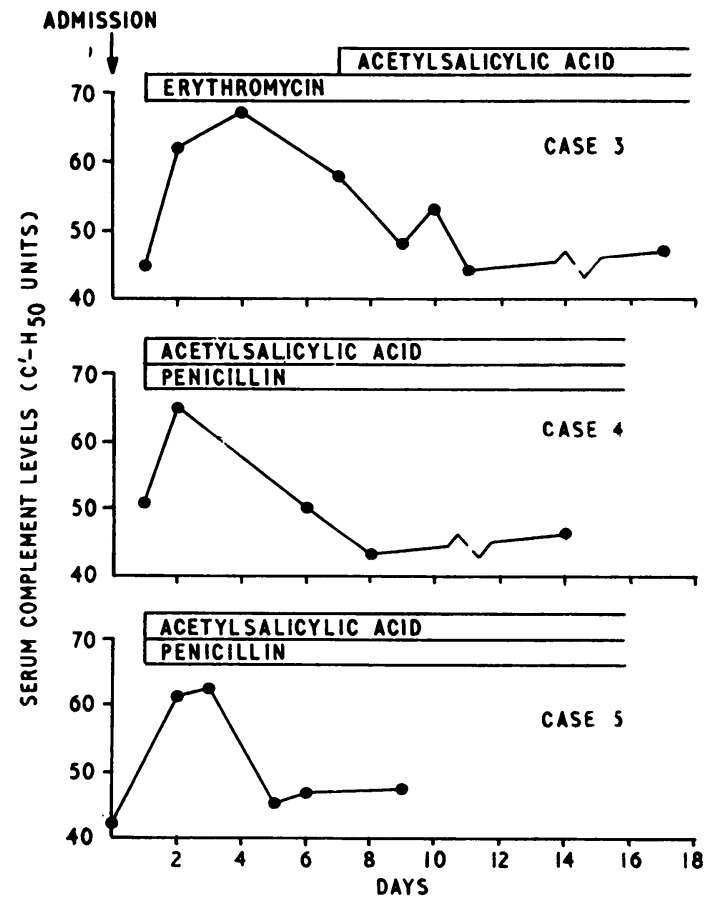

Fig. 4.-Secondary rise in serum complement levels in Cases 3 to 5 who had normal values on admission after starting penicillin treatment. 


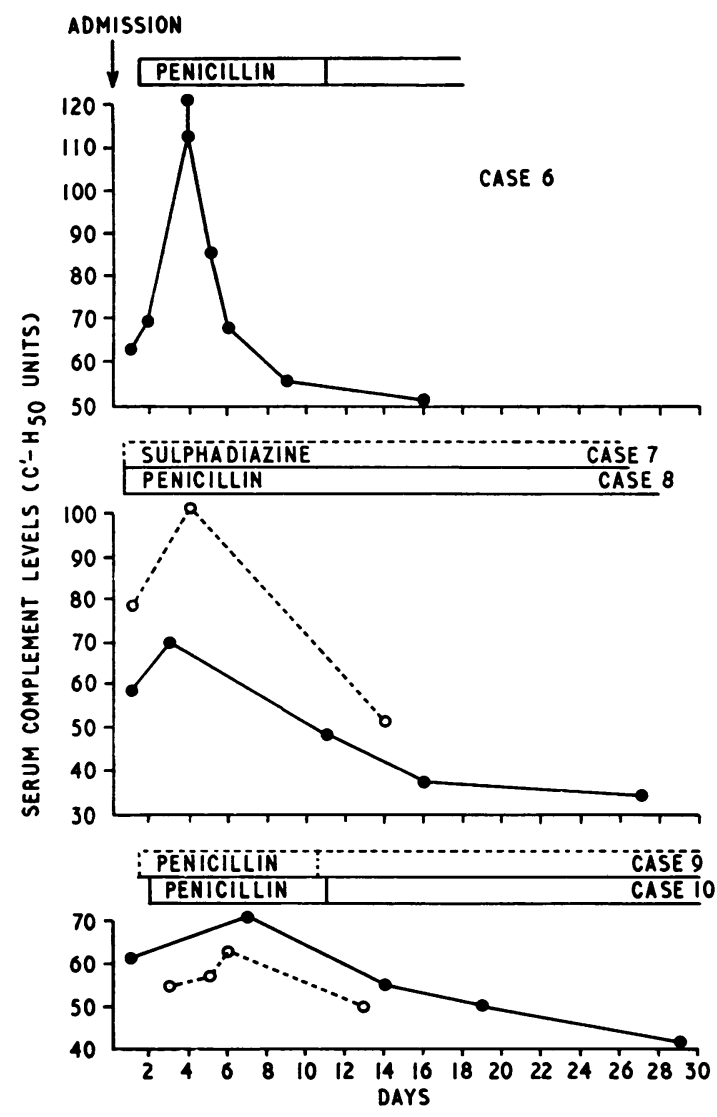

Fig 5.-Secondary rise in serum complement levels in Cases 6 to 10 who had raised levels on admission. The serum complement values returned to normal later.

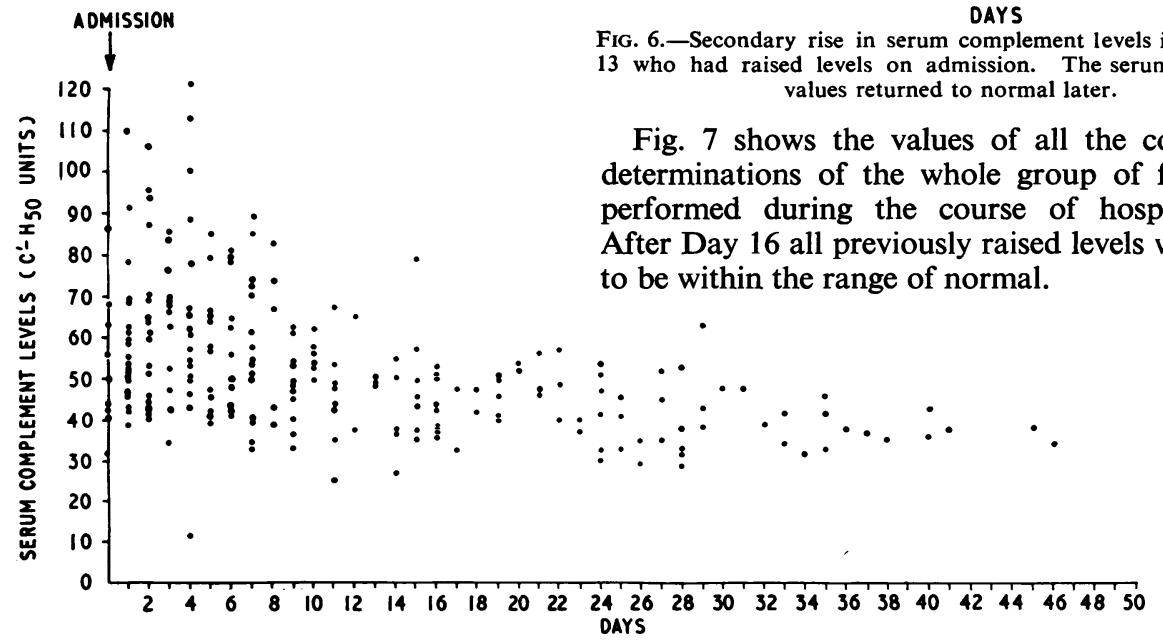

Fig. 7.-Composite chart of all serum complement determinations performed during the course of hospitalization of forty patients with acute rheumatic fever. Raised levels had returned to normal 16 days after starting treatment.

patients with raised complement levels admission.-These raised complement levels all returned to normal during the first 2 weeks after starting treatment. In twelve cases the return to normal was preceded by a sharp rise, as in Cases 6 to 10 and Cases 11 to 13 which are shown in Figs 5 and 6 respectively. In Case 6 the serum complement level had risen to $121 \cdot 1 \mathrm{C}^{\prime}-\mathrm{H}_{50}$ units on the fourth day of hospitalization.

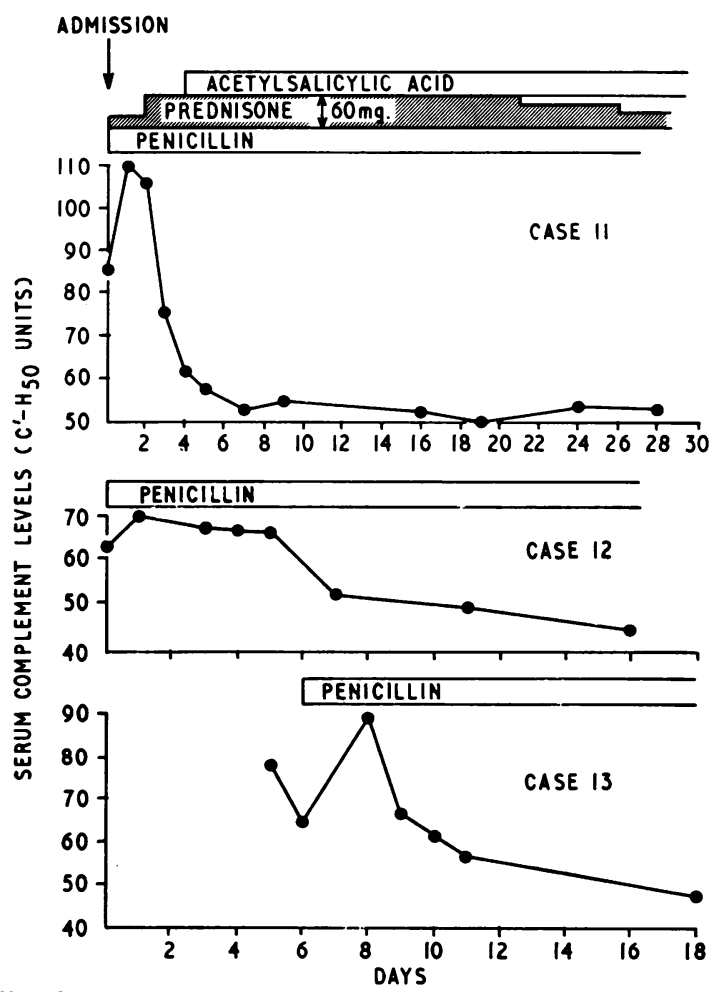

Fig. 6.-Secondary rise in serum complement levels in Cases 11 to values returned to normal later.

Fig. 7 shows the values of all the complement determinations of the whole group of forty cases performed during the course of hospitalization. After Day 16 all previously raised levels were found to be within the range of normal. 
Correlation of Complement Levels with Treatment: The treatment of these forty cases with acute rheumatic fever did not follow a predetermined protocol and was analysed in retrospect.

Antibiotic treatment consisted of penicillin in 38 cases, and erythromycin and sulphadiazine were used in two (Cases 3 and 7) because of penicillin hypersensitivity. All forty patients received salicylates in varying amounts sufficient to suppress the clinical manifestations of the disease. Steroids were given in addition to salicylates to four patients (e.g. Case 11).

The changes in serum complement levels observed during the hospitalization of 34 cases of acute rheumatic fever treated with penicillin and salicylates only are summarized in Table I, where they are analysed in two groups, A and B.

In Group A, of sixteen patients with normal complement levels on admission, eleven were shown to maintain normal values throughout their stay in hospital. In three cases a secondary rise in complement levels was observed after starting treatment. A significant fall in the complement level was seen in two patients.

In Group B serum complement levels returned to normal after starting treatment with penicillin in all the eighteen patients who had raised levels on admission. A secondary rise in complement was seen in seven cases of this group.

Persistent elevation of complement levels could not be demonstrated in any of the 34 cases of Groups A and B combined.

The treatment schedules of the thirteen patients shown in Figs 3 to 6 are given in detail in Table II, and the administration of penicillin to the other 27 patients (Cases 14 to 40 ) is shown in Table III (opposite).

TABLE I

CHANGES IN SERUM COMPLEMENT LEVELS OBSERVED DURING THE HOSPITALIZATION OF 34 CASES OF ACUTE RHEUMATIC FEVER TREATED WITH PENICILLIN AND SALICYLATES

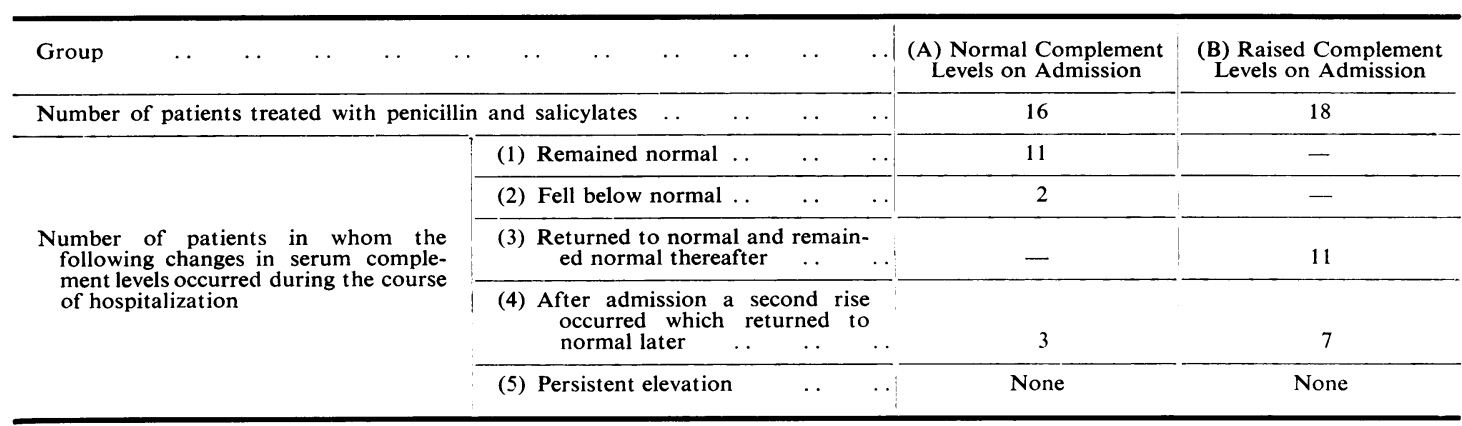

TABLE II

ANTIBIOTIC TREATMENT OF THIRTEEN PATIENTS WITH ACUTE RHEUMATIC FEVER. SERUM COMPLEMENT LEVELS ARE SHOWN IN FIGS 3 TO 6

\begin{tabular}{|c|c|c|c|c|c|c|c|}
\hline \multirow{2}{*}{$\begin{array}{l}\text { Patient } \\
\text { No. }\end{array}$} & \multirow{2}{*}{$\begin{array}{l}\text { Figure } \\
\text { No. }\end{array}$} & \multirow{2}{*}{$\begin{array}{l}\text { Age } \\
(\text { yrs) }\end{array}$} & \multicolumn{3}{|c|}{ Initial Treatment } & \multicolumn{2}{|c|}{ Prophylactic Treatment } \\
\hline & & & Drug & $\begin{array}{c}\text { Dosage } \\
\text { (units) }\end{array}$ & $\begin{array}{c}\text { No. of } \\
\text { Days }\end{array}$ & Drug & $\begin{array}{l}\text { Dosage } \\
\text { (units) }\end{array}$ \\
\hline $\begin{array}{l}1 \\
2\end{array}$ & 3 & $\begin{array}{r}6 \\
19\end{array}$ & $\begin{array}{l}\text { Pen. V. } \\
\text { Proc. Pen. }\end{array}$ & $\begin{array}{l}300,000 \text { 6-hrly } \\
600,000 \text { twice daily }\end{array}$ & $\begin{array}{l}15 \\
19\end{array}$ & $\begin{array}{l}\text { Pen. V. } \\
\text { Not recorded }\end{array}$ & 300,000 daily \\
\hline $\begin{array}{l}3 \\
4 \\
5\end{array}$ & 4 & $\begin{array}{l}26 \\
13 \\
19\end{array}$ & $\begin{array}{l}\text { Erythromycin } \\
\text { Proc. Pen. } \\
\text { Bicillin }\end{array}$ & $\begin{array}{l}250 \mathrm{mg} .6-\mathrm{6rly} \\
600,000 \text { daily } \\
1,200,000\end{array}$ & $\begin{array}{l}15 \\
10 \\
-\end{array}$ & $\begin{array}{l}\text { None } \\
\text { Bicillin } \\
\text { Bicillin }\end{array}$ & $\begin{array}{l}1,200,000 \\
1,200,000\end{array}$ \\
\hline $\begin{array}{r}6 \\
7 \\
8 \\
9 \\
10\end{array}$ & 5 & $\begin{array}{r}38 \\
15 \\
22 \\
5 \\
24\end{array}$ & $\begin{array}{l}\text { Proc. Pen. } \\
\text { Sulphadiazine } \\
\text { Proc. Pen. } \\
\text { Proc. Pen. } \\
\text { Proc. Pen. }\end{array}$ & $\begin{array}{l}600,000 \text { twice daily } \\
0 \cdot 5 \text { g. daily } \\
600,000 \text { twice daily } \\
600,000 \text { twice daily } \\
600,000 \text { twice daily }\end{array}$ & $\begin{array}{l}7 \\
10 \\
15 \\
10\end{array}$ & $\begin{array}{l}\text { Pen. V. } \\
\text { Sulphadiazine } \\
\text { Pen. V } \\
\text { Pen. V. } \\
\text { Bicillin }\end{array}$ & $\begin{array}{l}500,000 \text { twice daily } \\
0 \cdot 5 \text { g. daily } \\
200,000 \text { twice daily } \\
300,000 \text { daily } \\
1,200,000\end{array}$ \\
\hline $\begin{array}{l}11 \\
12 \\
13\end{array}$ & 6 & $\begin{array}{l}14 \\
22 \\
11\end{array}$ & $\begin{array}{l}\text { Proc. Pen. } \\
\text { Proc. Pen. } \\
\text { Proc. Pen. } \\
\text { Pen. V. }\end{array}$ & $\begin{array}{l}600,000 \text { twice daily } \\
600,0006 \text {-hrly } \\
600,00012-\text { hrly } \\
200,0003 \text { times daily }\end{array}$ & $\begin{array}{r}24 \\
11 \\
2 \\
52\end{array}$ & $\begin{array}{l}\text { Pen. V. } \\
\text { Bicillin } \\
\text { Bicillin } \\
\text { Pen. V. }\end{array}$ & $\begin{array}{l}200,000 \text { daily } \\
1,200,000 \\
1,200,000 \\
200,000 \text { twice daily }\end{array}$ \\
\hline
\end{tabular}


TABLE III

PENICILLIN TREATMENT OF 27 PATIENTS WITH ACUTE RHEUMATIC FEVER

\begin{tabular}{|c|c|c|c|c|c|c|}
\hline \multirow{2}{*}{$\begin{array}{l}\text { Patient } \\
\text { No. }\end{array}$} & \multirow{2}{*}{$\begin{array}{l}\text { Age } \\
\text { (yrs) }\end{array}$} & \multicolumn{3}{|c|}{ Initial Treatment } & \multicolumn{2}{|c|}{ Prophylactic Treatment } \\
\hline & & Drug & $\begin{array}{l}\text { Dosage } \\
\text { (units) }\end{array}$ & $\begin{array}{l}\text { No. of } \\
\text { Days }\end{array}$ & Drug & $\begin{array}{l}\text { Dosage } \\
\text { (units) }\end{array}$ \\
\hline 14 & 18 & $\begin{array}{l}\text { Proc. Pen. } \\
\text { Pen. V. }\end{array}$ & $\begin{array}{l}600,000 \text { 6-hrly } \\
600,000 \text { 6-hrly }\end{array}$ & $\begin{array}{l}5 \\
6\end{array}$ & $\begin{array}{l}\text { Not recorded } \\
\text { Not recorded }\end{array}$ & \\
\hline 15 & 7 & Pen. V. & 400,0003 times daily & 12 & Pen. V. & 400,000 daily \\
\hline 16 & 25 & Proc. Pen. & 600,000 twice daily & 17 & Bicillin & $1,200,000$ \\
\hline 17 & 13 & Pen. V. & 300,000 4-hrly & 10 & Pen. V. & 200,000 twice daily \\
\hline 18 & 5 & Proc. Pen. & 600,000 12-hrly & 20 & Not recorded & \\
\hline 19 & 14 & Proc. Pen. & 600,000 twice daily & 10 & Bicillin & $1,200,000$ \\
\hline 20 & 9 & Proc. Pen. & 600,000 daily & 30 & Not recorded & \\
\hline 21 & 7 & $\begin{array}{l}\text { Proc. Pen. } \\
\text { Pen. V. }\end{array}$ & $\begin{array}{l}600,000 \text { twice daily } \\
400,0006 \text {-hrly }\end{array}$ & $\begin{array}{r}2 \\
18\end{array}$ & Pen. V. & 400,000 daily \\
\hline 22 & 6 & Pen. V. & 300,000 6-hrly & 37 & Pen. V. & 300,000 daily \\
\hline 23 & 5 & Pen. V. & 400,000 8-hrly & 19 & Pen. V. & 200,000 twice daily \\
\hline 24 & 8 & $\begin{array}{l}\text { Proc. Pen. } \\
\text { Pen. V. }\end{array}$ & $\begin{array}{l}600,000 \text { twice daily } \\
300,0006 \text {-hrly }\end{array}$ & 20 & Pen. V. & 300,000 daily \\
\hline 25 & 12 & $\begin{array}{l}\text { Proc. Pen. } \\
\text { Pen. V. }\end{array}$ & $\begin{array}{l}600,000 \text { 6-hrly } \\
200,000 \text { 6-hrly }\end{array}$ & $\begin{array}{r}2 \\
18\end{array}$ & Pen. V. & 200,000 twice daily \\
\hline 26 & 23 & Proc. Pen. & $600,00012-$ hrly & 16 & Bicillin & $1,200,000$ \\
\hline 27 & 12 & Pen. V. & 400,000 8-hrly & 10 & Bicillin & $1,200,000$ \\
\hline 28 & 8 & Proc. Pen. & $1,200,000$ 6-hrly & 7 & Pen. V. & 200,000 8-hrly \\
\hline 29 & 25 & Proc. Pen. & $600,00012-$ hrly & 10 & Pen. V. & 200,000 daily \\
\hline 30 & 8 & Pen. V. & 400,000 8-hrly & 20 & Pen. V. & 400,000 daily \\
\hline 31 & 34 & Proc. Pen. & 600,000 twice daily & 10 & Pen. V. & 200,000 twice daily \\
\hline 32 & 14 & Pen. V. & 300,000 8-hrly & 7 & Pen. V. & 300,000 8-hrly \\
\hline 33 & 16 & Proc. Pen. & 600,000 twice daily & 10 & Bicillin & $1,200,000$ \\
\hline 34 & 23 & Pen. V. & 200,000 & & Bicillin & $1,200,000$ \\
\hline 35 & 11 & Proc. Pen. & 600,000 twice daily & 7 & Pen. V. & 300,000 twice daily \\
\hline 36 & 4 & Proc. Pen. & 300,000 8-hrly & 12 & Pen. V. & 300,000 daily \\
\hline 37 & $x \times 48$ & $\begin{array}{l}\text { Proc. Pen. } \\
\text { Bicillin }\end{array}$ & $\begin{array}{l}600,000 \text { twice daily } \\
1,200,000\end{array}$ & 2 & Pen. V. & 200,000 twice daily \\
\hline 38 & 7 & Proc. Pen. & 600,000 twice daily & 10 & Pen. V. & 200,000 twice daily \\
\hline 39 & 14 & Proc. Pen. & 600,000 twice daily & 10 & Bicillin & $1,200,000$ \\
\hline 40 & 5 & Pen. V. & 300,000 8-hrly & 10 & Pen. V. & 200,000 daily \\
\hline
\end{tabular}

\section{Discussion}

Fischel and others $(1949,1958)$ and Williams and Law (1958) have reviewed the literature concerning the variations in serum complement levels which occur in patients with acute rheumatic fever. The following conclusions can be drawn from these papers:

(1) Serum complement levels tend to be raised in the majority of cases during the early part of acute rheumatic fever.
(2) A rise in complement levels may follow the onset of a sore throat, thus preceding the appearance of the clinical manifestations of rheumatic fever. Therefore, the infection with haemolytic streptococci may be regarded as the possible cause of this rise.

(3) Treatment with salicylates had no appreciable effect upon serum complement levels.

(4) The rise in serum complement levels was shown to persist for as long as 7 weeks in some patients with rheumatic fever. In chronically active rheumatic fever, with the duration of the disease ranging from 2 to 18 
months, complement values were found to be raised in four out of six cases.

(5) Serial determinations of complement levels performed at weekly intervals during the course of the illness failed to demonstrate a uniform or consistent pattern.

The results of the present study of forty cases differ significantly from the previous studies summarized above. First, serum complement levels returned to normal within 2 weeks, and remained normal thereafter in all those with raised levels on admission, and secondly several relatively uniform patterns of serial complement levels appeared.

(1) Normal complement levels throughout the course of observation (fourteen cases).

(2) Low serum complement (two cases, Fig. 3).

(3) Raised complement values returning to normal directly within 2 weeks (nine cases).

(4) Complement levels showing a secondary rise above that found on admission. This rise was seen in three patients with normal values on admission (Fig. 4). The largest group of nine patients with a similar secondary rise came from among those who had raised levels at the first determination (Figs 5 and 6).

The secondary rise in serum complement levels deserves further comment, since it may indicate that complement consumption was occurring during the acute phase of rheumatic fever.

The various factors that influence serum complement levels were reviewed by Schmidt (1959). In the sixty normal individuals in this study the levels were found to range between 25 and 59.4 (mean 40.2) $\mathrm{C}^{\prime}-\mathrm{H}_{50}$ units. The value for mean normality reported by Fischel and others (1949) was $37 \cdot 7$, by Wedgwood and Janeway (1953) it was 4.7.7, and by Williams and Law (1958) it was $44 \cdot 0 \mathrm{C}^{\prime}-\mathrm{H}_{50}$ units. While a relatively wide range was demonstrated in different normal subjects, the serum complement level of any single individual proved to remain almost constant, with fluctuations of less than $5 \mathrm{C}^{\prime}-\mathrm{H}_{50}$ units over 4 to 6 months (Williams and Law, 1958).

Complement consumption and complement production or release determine the complement level. Complement consumption may be low, permitting complement production to maintain a constant level. Such conditions of low-degree complement disappearance would escape detection. The significant fluctuations in rheumatic fever are indicative of a more striking involvement of the complement system. Low complement levels may not be due to increased consumption alone, since production may also be reduced simultaneously. Raised serum complement levels, however, must be regarded as an expression of an increased production of comple- ment which may or may not be accompanied by increased complement consumption.

It may be postulated that, in all cases in this study who showed the secondary rise in complement levels, complement consumption and production were both increased. The balance between the two determined the first complement value on admission. A relatively sudden reduction in complement consumption would lead to a secondary rise if production should continue at an increased rate for any length of time.

Similar rising complement levels following the cessation of increased complement consumption were first demonstrated by Dick (1912), who measured complement levels during the natural course of lobar pneumonia. With the occurrence of the crisis, complement levels were shown to fall precipitately, and this was followed by a significant rise above normal during the next 2 to 4 days.

We are inclined to regard the secondary rise observed in this study as indirect evidence for a significant complement consumption which terminates relatively abruptly. In Case 13 (Table II) treatment with penicillin was delayed and the serum complement levels remained high. After the administration of penicillin the secondary rise occurred during the following 5 days (Fig. 6), and complement values then returned to normal. The remaining eleven cases who showed a secondary rise in serum complement had the same interval between the administration of penicillin (or erythromycin and sulphadiazine in two cases) and the appearance of the complement rebound. This strongly suggested that antibiotic treatment was in some way instrumental in the creation of the secondary rise in complement values.

It appears unlikely that penicillin has the capacity to raise the serum complement levels directly, since no significant changes were observed in eleven patients with normal complement levels on admission who were treated with penicillin (Group A, Table I).

Correlation of Treatment with the Clinical and Serological Data of All Forty Cases:

(1) Administration of Salicylates.-This did not significantly influence complement values since they remained normal throughout the course of observation in fourteen cases. The secondary rise in complement was not caused by salicylates, since it was observed at a time when salicylates were not given (Case 3, Table II, Fig. 4). All complement values returned to normal while salicylates were still being administered.

The anticomplementary action of aspirin in vitro. 
which was reported by van Oss, Friedmann, and Fontaine (1961), was shown by Anderson (1961) to be caused by a lowering of the $\mathrm{pH}$ with non-specific and reversible inhibition of complement activity. This inhibition does not occur in vivo.

(2) Influence of Steroid Medication on Complement Values.-This could not be determined in this study because of the small number of cases treated.

(3) Interval between Treatment with Penicillin (or other antibiotics and sulphadiazine) and Serum Complement Changes.-This was two-fold:

(A) The secondary rise in serum complement occurred 2 to 4 days after starting treatment;

(B) Raised complement levels returned to normal within less than 2 weeks after antibiotic treatment in all patients who had high complement values on admission.

Thus, we are led to believe that the treatment with antibiotics was probably decisive in removing the stimulus that was responsible for the elevation of serum complement. The demonstration of the persistence of high complement values in patients not treated with penicillin would support this impression. However, all forty cases in this study were treated at random without a predetermined therapeutic programme.

The difference between the results of this study and those of Fischel and others (1949) suggests that some of their cases with persistently raised complement levels were perhaps not treated with antibiotics or sulphadiazine. Unfortunately, however, a correlation with treatment other than with salicylates was not recorded and these cases cannot therefore serve as a dependable control group.

Fischel and his co-workers presented evidence which suggests that infection with haemolytic streptococci is responsible for the rise in serum complement levels. Consequently it may be postulated that treatment bringing about the eradication of this organism would permit the complement levels to return to normal. It is our opinion that the results of the present study lend strong support to this theory.

The determination of serum complement levels in acute rheumatic fever may serve thus to measure the efficiency of antistreptococcal treatment.

\section{Summary}

Serum complement levels were studied in a longitudinal fashion throughout the hospitalization of forty patients with acute rheumatic fever.
In a group of nineteen patients who had normal serum complement values on admission, the levels remained normal throughout the course of observation in fourteen and fell to below normal in two. In a group of 21 patients with raised serum complement values on admission all returned to normal in less than 16 days.

A secondary rise in serum complement levels above the initial values was observed in twelve patients after starting treatment with antibiotics. This rebound phenomenon may be regarded as suggestive of increased complement consumption in acute rheumatic fever.

Correlation of clinical and serological data suggests that treatment with penicillin (or erythromycin or sulphadiazine) resulted in all raised complement values returning to normal within 16 days. Treatment with salicylates had no significant influence on complement levels. These data support the impression that the rise in serum complement which occurs in acute rheumatic fever is caused predominantly by the infection with haemolytic streptococci.

The implications of these findings are discussed, together with a brief review of the literature.

We are indebted to Dr. J. Edmund Bradley and the house staff of the Department of Paediatrics for permitting the inclusion of some of their cases in this study. The technical assistance of Miss Elaine Winokour and Miss Birke Mersmann is gratefully acknowledged. Grants in support of these investigations have been received from the National Institute of Arthritis and Metabolic Diseases, National Institutes of Health, United States Public Health Service (No. 2A-5059 and A-3173), and from the Maryland Chapter of the Arthritis and Rheumatism Foundation.

\section{REFERENCES}

Anderson, K. W. (1961). Nature (Lond.), 191, 1012. Dick, F. G. (1912). J. infect. Dis., 10, 383.

Fischel, E. E., Pauli, R. H., and Lesh, J. (1949). J. clin. Invest., 28, 1172.

- Frank, C. W., Boltax, A. J., and Arcasoy, M. (1958). Arthr. and Rheum., 1, 351.

Jones, T. Duckett (1944). J. Amer. med. Ass., 126, 481. Mayer, M. M. (1961). In Kabat, E. A., and Mayer, M. M., "Experimental Immunochemistry", 2nd ed., pp. 149-53. Thomas, Springfield, Ill.

Schmidt, H. (1959). Fortschr. Immunitätforsch., 1, No. 1, p. 31 .

U.K. and U.S.A. Joint Report (1955). Circulation, 11, 343.

-1 (1960). Ibid., 22, 503.

Van Oss, C. J., Friedmann, J. C., and Fontaine, M. (1961). Nature (Lond.), 189, 147. 
Wedgwood, R. J. P., and Janeway, C. A. (1953). Pediatrics, 11, 569.

Williams, R. C., and Law, D. H. (1958). J. Lab. clin. Med., 52, 273.

Effet du traitement par la pénicilline sur le taux du complément sérique dans le rhumatisme articulaire aigu

\section{RÉSUMÉ}

Le taux du complément sérique fut étudié en série chez quarante malades atteints de rhumatisme articulaire aigu, pendant leur séjour entier à l'hôpital.

Dans un groupe de 19 malades dont le taux du complément sérique était normal à leur entrée, ce taux demeura normal pendant toute la période d'observation chez quatorze d'entre eux et tomba en dessous de la normale chez deux autres. Dans un groupe de 21 malades dont le chiffre du complément sérique se trouvait augmenté à leur entrée, ce chiffre retourna à la normale en moins de 16 jours.

Une augmentation secondaire du taux du complément sérique au dessus de la valeur initiale fut observée chez douze malade après avoir commencé un traitement par des antibiotiques. Ce rebondissement peut indiquer une consommation augmentée de complément dans le rhumatisme articulaire aigu.

Une corrélation des données cliniques et sérologiques indique que le traitement par la pénicilline (ou l'érythromycine ou la sulfadiazine) a produit le retour à la normale en dedans de 16 jours de tous les taux de complément augmentés. Le traitement par des salicylates n'a exercé aucun effet appréciable sur les taux de complément. Ces données renforcent l'impression que l'augmentation du complément sérique survenant dans le rhumatisme articulaire aigu est due surtout à l'infection par le streptocoque hémolytique.
On discute les implications de ces résultats et on passe brièvement en revue la littérature sur ce sujet.

Efecto del tratamiento con penicilina sobre los niveles del complemento sérico en el reumatismo poliarticular agudo

\section{SUMARIO}

Los niveles del complemento sérico fueron estudiados en serie en cuarenta enfermos con reumatismo poliarticular agudo durante el entero tiempo de su hospitalización.

En un grupo de 19 enfermos con valores del complemento sérico normales al tiempo de su admisión, estos valores permanecieron normales durante todo el período de observación en catorce de ellos y cayeron debajo de lo normal en dos. En un grupo de 21 enfermos con cifras del complemento sérico elevadas al tiempo de la admisión, se observó una vuelta a lo normal en menos de 16 dias.

Un alza secundaria de los niveles del complemento sérico por encima de las cifras iniciales fué observada en doce enfermos después de haber empezado el tratamiento con antibióticos. Este fenómeno de rebote puede indicar una consunción aumentada de complemento en el reumatismo poliarticular agudo.

La correlación de los datos clìnicos y serológicos indica que el tratamiento con penicilina (o eritromicina o sulfadiazina) había resultado en el retorno a lo normal dentro de 16 días de todos los niveles aumentados del complemento. El tratamiento salicilico no ejerció efecto apreciable sobre los niveles del complemento. Estos datos fortalecen la impresión de que el aumento del $§$ complemento sérico en el curso del reumatismo poliarticular agudo se debe principalmente a la infección por el estreptococo hemolítico.

Se discuten las implicaciones de estos resultados: y se revista brevemente la literatura sobre este sujeto. 